Where Have All the Factories Gone? : Growth and Concentration of Sub-National Manufacturing Activity in India

K.V.Ramaswamy

Indira Gandhi Institute of Development Research, Mumbai May 2019 


\title{
Where Have All the Factories Gone? : Growth and Concentration of Sub-National Manufacturing Activity in India
}

\author{
K.V.Ramaswamy \\ Email(corresponding author): swamy@igidr.ac.in
}

\begin{abstract}
The spatial distribution of manufacturing across the states of India is analyzed covering the period 2004-05 to 2015-16. We found that the spatial concentration of manufacturing activity has increased since 2004-05. More industrialized states (example Maharashtra, Gujarat and Tamil Nadu) are found to have continued their dominance measured in terms of their share of output, factories and workers in manufacturing. They are observed to have captured a greater share of incremental growth of factories and workers. This outcome may be attributed to their comparative advantage due to agglomeration economies. Differences in the net entry of factories (and workers) in registered and unregistered segments of manufacturing are observed between different states of India. The estimates of net entry of factories in five selected industry groups in registered manufacturing are found to be consistent with agglomeration at the sectoral level.
\end{abstract}

Keywords: Agglomeration,Concentration, Inequality, Spatial, Manufacturing, Net Entry

JEL Code: O14,O17,O25,R12

\section{Acknowledgements:}

This paper was prepared for the IHD National Conference on Growth and Regional Development in India held during 13-15 May 2019 in New Delhi. I wish to thank the discussants Dr. Ajit Ranade and Dr. Aditya Bhattacharjea, and other participants for their comments. Research assistance provided by Leena Bhattacharya is thankfully acknowledged. The usual disclaimer applies. 


\title{
Where Have All the Factories Gone? :
}

\section{Growth and Concentration of Sub-National Manufacturing Activity in India}

\section{K.V.Ramaswamy}

\begin{abstract}
The spatial distribution of manufacturing across the states of India is analyzed covering the period 2004-05 to 2015-16. We found that the spatial concentration of manufacturing activity has increased since 2004-05. More industrialized states (example Maharashtra, Gujarat and Tamil Nadu) are found to have continued their dominance measured in terms of their share of output, factories and workers in manufacturing. They are observed to have captured a greater share of incremental growth of factories and workers. This outcome may be attributed to their comparative advantage due to agglomeration economies. Differences in the net entry of factories (and workers) in registered and unregistered segments of manufacturing are observed between different states of India. The estimates of net entry of factories in five selected industry groups in registered manufacturing are found to be consistent with agglomeration at the sectoral level.
\end{abstract}




\section{Introduction}

Differences in economic performance between states or subnational units have always been important in policy debates in India. Particularly so in the context of allocation development expenditures and sharing of tax revenues. Analyses of disparities have covered issues of differences in income levels to dimensions of human development. Over the years they have assumed significance as instances of unequal benefits of economic growth (reduction of poverty and income inequality) have been observed to be more widespread. The uneven growth across sub-national units (states or provinces) in an economy suggests that the growth processes have created differential economic opportunities across regions. In India some states have forged ahead (Maharashtra, Gujarat and Haryana) seriously leaving behind others (Bihar and Uttar Pradesh). If one looks at the differences in levels of income then one finds that the per capita State Domestic Product of Maharashtra is 5 times that of Bihar in 2015$16^{1}$. Structural changes within states have been broadly similar with a decline in the income share of agriculture, moderate rise in the share of industry and substantial rise in the share of services consistent with the structural change at the aggregate all India level. Closer observation reveals large interstate disparities in growth and employment within individual sectors like services and manufacturing (Ramaswamy, 2007 and Ramaswamy, 2017). The policy of economic integration through trade and investment liberalization since 1991 could have unevenly impacted spatial development. Trade openness has been argued to have contributed to regional income inequalities in developing countries (Kanbur and Venables 2005, and Rodriguez-Pose 2012). In India several studies of regional income inequality in India have found that spatial income inequality has increased in the post reform period (Ahluwalia 2000, Nayyar 2008, Ramaswamy 2007). Interstate disparities in manufacturing growth and concentration have been found to be one of the factors in accentuating the interstate differences in income levels (Lall and Chakravorty, 2005). This is not entirely surprising 
given that private investment and location decisions would be driven by market incentives in liberalized trade and investment environment initiated since 1991.

The objective of this paper is to study the spatial distribution of manufacturing across the states of India. We examine the changes in the share of subnational states in total manufacturing sector of India. The study covers the period 2004-05 to 2015-16.The natural question that arises is why the focus on manufacturing sector? First, manufacturing has been the sector most subjected to economic policy reform and at the forefront of India's industrial licensing, trade and foreign investment liberalization since 1991. Second, structural transformation of India with higher shares of manufacturing has been widely perceived to be critical to achieve accelerated growth and employment (Ghose, 2013). The share of manufacturing in India's GDP has averaged around 15 to 16 per cent since mid-1990s. Given this context, analysis of spatial concentration of manufacturing activity in recent years will contribute to our understanding of economic transformation issues at the subnational level ${ }^{2}$. The geographic concentration of economic activity is driven by the forces of agglomeration (centripetal). These now familiar forces are market size (scale economies and linkages), thick labour markets and external economies (Krugman, 1998). They could give rise to selfreinforcing processes in which initial advantages in certain states (the core) had accumulated and relegated other states to disadvantaged situations (the periphery). In other words, increasing returns and agglomeration can produce a core-periphery pattern of industrialization (Krugman, 1991 and 1998) ${ }^{3}$. This insight can serve to illuminate certain recent observed trends in spatial concentration of manufacturing in India.

\section{Economic Reform, Firm entry and Industrial Location Policy ${ }^{4}$}

Economic reforms relaxed the entry restrictions on domestic and foreign firms. It liberalized access to intermediate inputs, capital goods and technology. The location restrictions on industries were removed. It is useful to summarize the policy reform to put the 
discussion in perspective. The foremost instrument of industrial policy was the industrial licensing for private entrepreneurs based on Industrial Regulation Act of 1956.The new industrial policy of 1991 abolished industrial licensing except in 18 industries. The major areas of trade reform included reduction of average tariff rates, the removal of licensing and other non-tariff barriers on all imports of intermediate and capital goods, the elimination of trade monopolies of the state trading agencies and the simplification of trading regime. The mean tariff was reduced from 128 per cent before July 1991 to 35 per cent by 1997-98 and later it was reduced to 30 percent in 2001 . Ninety five per cent of the tariff lines were freed from Non-Tariff Barriers (NTBs) in 2001. Restrictions on foreign direct investment (FDI) were relaxed in 1991. In the years prior to 1991 , FDI was permitted only up to 40 per cent in certain industries, known as 'Appendix I Industries' subject to the discretionary approval by the government. In 1991, FDI was allowed up to 51 per cent equity in these industries under the 'automatic route'. This was later liberalized to enable setting up of 100 per cent subsidiaries in the manufacturing sector in 1997. The list of products reserved for exclusive manufacture by small-scale industries have been progressively removed from the reservation list enabling large domestic and foreign firms to enter those product lines.

\subsection{Industrial Location Policy}

The concern for regional disparity was expressed very early in India in the Industrial Policy Statement of 1956. Multiple instruments were brought into use during the 1970s and 1980s in order to achieve the desired objective of industrial dispersal ${ }^{5}$. They may be fall broadly into two types ${ }^{6}$ : (i) policies that influenced inter regional distribution of industry (ii) policies that impacted intra-regional distribution of industries. Use of industrial licensing policy to direct investment into backward or 'no industry' districts, prohibiting heavy industry from metropolitan areas; the location of public sector plants in backward states (Bihar, Madhya Pradesh and Orissa), pricing and distribution policy for intermediate inputs were important 
ways. All these fall under the first category. Applications for setting up units in backward areas were favoured and this showed up in the higher share of letters of intent and total licenses. The most powerful (policy) was the control of distribution and pricing of intermediate inputs like coal, cement and steel. This policy was implemented through the operation of freight equalization policy. This policy equalized across states the prices of coal, steel and cement. As a consequence, states in the Eastern region rich in these resources lost their natural competitive advantages. Other states in the Northern and Western regions that were not producers of these commodities were the beneficiaries. Later this policy was discontinued beginning with the decontrol of cement industry in 1989.

Within or Intra state distribution of industries were influenced by another set of policies that included the central government capital subsidy schemes, transport subsidy for industries in hilly backward areas, income tax concessions for new industrial units in backward districts that permitted 20 per cent deduction of profits in the computation of taxable income, and financial assistance at below normal lending rates by financial institutions. The latter is reported to be quite successful as the share of backward areas in the financial assistance sanctioned and disbursed by the All India Financial Institutions is found to be between 40 to 50 percent since the mid-1970s. Further the industrial licensing system was used to restrict the location of new industrial units within certain limits of large metropolitan cities. The Industrial Policy Statement of 1977 prohibited the location of new industrial units above a certain size on all cities with a population of more than 500,000 . All these policy rules clearly suggest a serious intension on the part of government's industrial policy to induce industries to locate away from existing locations with high degree of industrial concentration.

The industrial policy statement of 1991 that liberalized industrial regulatory rules by delicensing of industries removed all restrictions regarding location of industries. It retained 
the licensing requirement for setting up an industry within 25 Kilometers of cities with population more than one million in 1991. Environmental, pollution and other local use restrictions have been continued. All other incentives except income tax concessions for backward districts were withdrawn. Later in 2001, the Parthasarathy Shome committee on tax policy for the tenth plan advised the abolition of income tax concessions for regional industrial development. The approach of the central government during the era of economic reforms is that provision of infrastructure is more important than income tax concessions for encouraging economic activity in backward regions. The state governments on their part have continued many fiscal incentives like sales tax exemption etc. to attract domestic and foreign investment to their states.

In 2003, the Government of India initiated the following incentive package in order to attract industrial investments and generate employment in the states of Uttarakhand and Himachal Pradesh ${ }^{7}$. First, the new industrial units set up in 'designated' industrial estates/growth centers were entitled to: (a) 100 per cent excise duty exemption for a period of 10 years from the date of commencement of commercial production. (b) 100 per cent corporate income tax exemption for an initial period of five years and thereafter between 25 and 30 per cent for a further period of five years. (c) All new firms and existing units (upon substantial expansion) in the notified locations would be eligible for capital investment subsidy equaling 15 per cent of their investment in plant and machinery, subject to a ceiling of Rs. 3 million. All of these exemptions (a), (b), and (c) were available to existing industrial units depending on their "substantial expansion" (if they increased the value of fixed capital investment in plant and machinery by at least 25 per cent. Second, a list of 'thrust sector' industries was compiled that would be eligible for the benefits listed above irrespective of whether they located in an industrial estate or not. We may note that central excise duty rates varied between 8 per cent and 16 per cent and therefore these tax exemptions were 
presumably large enough to incentivize firms to enter the two states, namely, Himachal Pradesh and Uttarakhand. It is important to record that the central excise tax exemption was removed on 31st March 2010, and the income tax exemption was removed on the 31st of March $2012^{8}$. However, any new industrial units set up or existing units undertaking substantial expansion in these states prior to the above dates would continue to be eligible for these benefits for a period of 10 years from the date of publication of notification.

\section{Inter-State Differences in Income ${ }^{9}$}

Income differences between citizens in a country consisting of different spatial units, like states, could be decomposed into two parts. First is the within inequality that is income differences within the state and the second is the between component that is due to average income differences between states. If all the citizens within a given state could be assumed to have same mean income of that state then, one could ask, how much of observed inequality could be attributed to differences in mean income between states. One must note State Domestic Product (SDP) data do not capture the value of remittances received by residents of different states. Use of SDP data results in the under estimation of average income of residents in a state. This is particularly serious in the case of Kerala which has high income from remittance. One could use per capita consumption expenditure to get over this limitation. We have not estimated mean per capita consumption of different states in India. Available data indicates that per capita consumption by state is correlated with per capita income. Other studies using per capita consumption have reported that inequality has increased in recent years.

Data on per capita SDP of 22 selected states in India for two selected years (2004-05 and 2013-14) is presented in Table 1. In Table 3 we have also presented the ratio of each state's income to the poorest Indian state that is Bihar. The relative difference of each states income to the poorest state has marginally declined over the last ten years. However the 
absolute difference in per capita income between the richest state (Goa) and the poorest State (Bihar) has increased by more than 80 percent in the last decade.

\section{Table 1: Disparities in Real Per Capita Income between States in India}

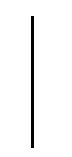

\section{States and Union Territories (UT)}

1 Andhra Pradesh

2 Bihar

3 Chhattisgarh

4 Goa

5 Gujarat

6 Haryana

7 Himachal Pradesh

8 Jharkhand

9 Karnataka

10 Kerala

11 Madhya Pradesh

12 Maharashtra

13 Odisha

14 Punjab

15 Rajasthan

16 Tamil Nadu

17 Telangana

18 Uttar Pradesh

19 Uttarakhand

20 West Bengal

21 Delhi

22 Puducherry India Mean for 22 States

\section{4-2005}

25959

7914

18559

76968

32021

37972

33348

18510

26882

32351

15442

36077

17650

33103

18565

30062

24409

12950

24726

22649

63877

48302

24143

$15,804.5$
2013-14

42170

15506

28373

137401

63168

67260

54494

28882

46012

58961

26853

69097

24929

49529

31836

62361

48881

19233

59161

36293

118411

94787

39904

30144.7
Ratio of State's income to the

poorest State:

2005

328.0

100.0

234.5

972.6

404.6

479.8

421.4

233.9

339.7

408.8

195.1

455.9

223.0

418.3

234.6

379.9

308.4

163.6

312.4

286.2

807.1

610.3

305.1

199.7
Ratio of State's income to the

poorest State:

2014

272.0

100.0

183.0

886.1

407.4

433.8

351.4

186.3

296.7

380.2

173.2

445.6

160.8

319.4

205.3

402.2

315.2

124.0

381.5

234.1

763.6

611.3

257.3

194.4

* Per Capita SDP at constant 2004-05 prices

Source: EPWRF On Line Data Base available at http://www.epwrfits.in

\subsection{Spatial Income Inequality}

Two widely used measures of dispersion are the Gini Coefficient and the Coefficient of Variation (CV) with and without population weights. Population weighted $\mathrm{CV}$ is our preferred measure as India is a country with large differences in population size between 
states. We have estimated both these measures of inequality for the period 2004-05 to 201213 using per capita NSDP data for 22 states of India. These two measures are shown in Figure 1. One could clearly see that spatial inequality has not declined in the last nine years. Our estimates are consistent with those reported by Lessmann (2014) which covered the period 1980 to 2005. To quote Lessmann "The case of India shows that the strong growth period, which started at the beginning of the 1990s, has increased spatial inequality significantly, and no turning point has been reached yet" (Lessmann 2014, page 38). In this context, we shall turn to analyze changes in the spatial or geographical concentration of manufacturing in India.

\section{Spatial Concentration of Manufacturing}

The flip side of industrial growth in India is the spatial concentration of industries. We have examined the distribution of manufacturing output in 14 major States of India as listed in Table 2. The data for Bihar, Madhya Pradesh and Uttar Pradesh have been made consistent by including data on Jharkhand, Chhattisgarh and Uttarakhand respectively. These 14 states have large populations and together have a share more than 93 per cent of India's population. Their share in India's registered manufacturing GDP was 79 per cent in 2004-05. In the beginning of 1980s the top 3 states in terms of their share in Gross State Domestic Product (GSDP) were Maharashtra, West Bengal and Tamil Nadu (Table 2). Together their estimated share is found to be 47.5 per cent in 1980-81. These three states had received 56 per cent of the industrial licenses issued between 1953 and $1961^{10}$. In 1970-1 their combined share of value added in registered manufacturing was above 50 per cent. Between 1970 and 1980 there was little redistribution of value added except for the fall in the share of West Bengal (Mohan 1993, p.18). 
Figure 1: Indices of Spatial Income Inequality in India: 2005-2014

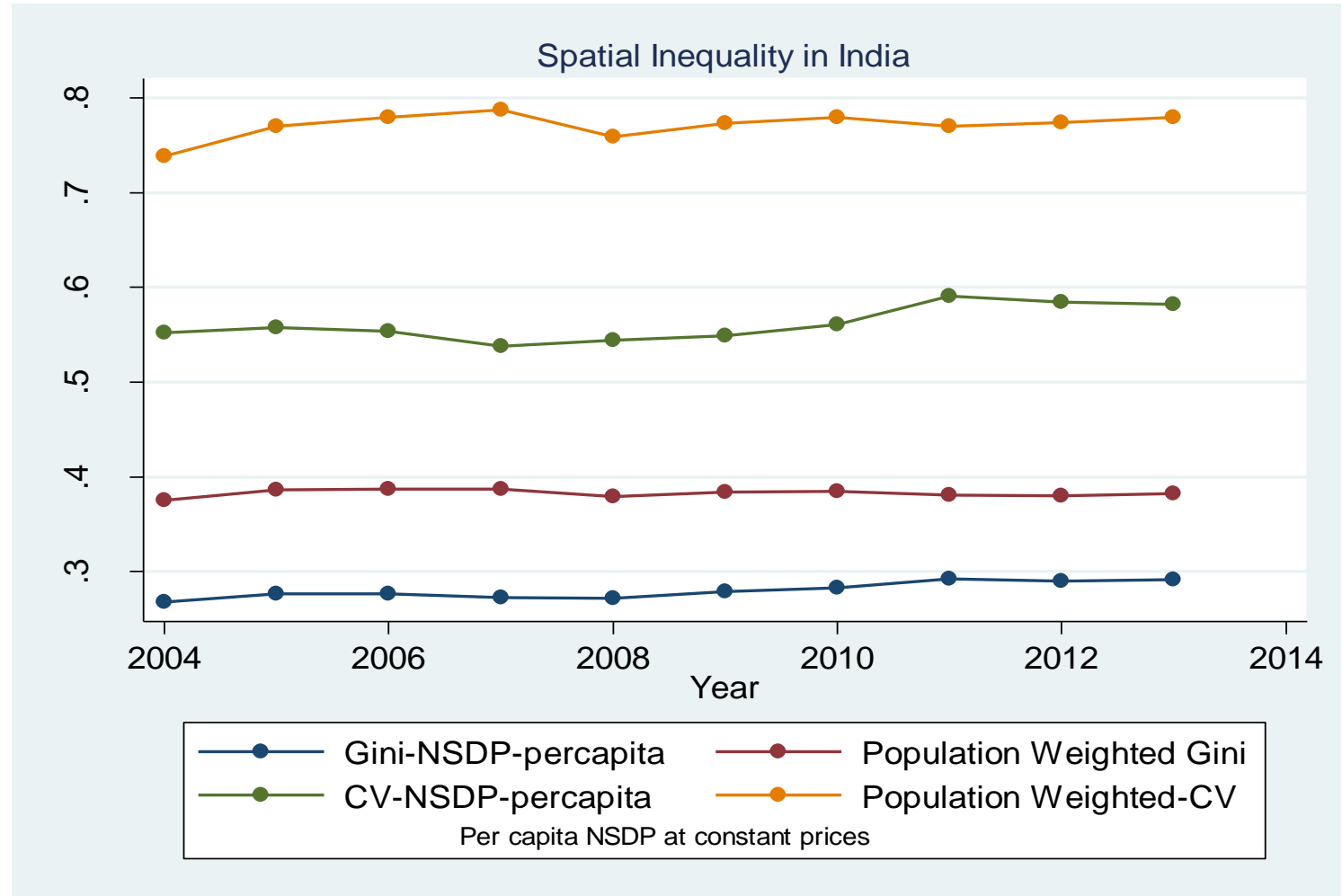

The share of these three states in total registered manufacturing was higher than their share in total NSDP in the 1970s. In other words, the spatial inequality of registered manufacturing was probably increasing in the $1970 \mathrm{~s}^{11}$. It started declining in the $1980 \mathrm{~s}$. We need to consider the distribution of total manufacturing GSDP because the unregistered factories constitute substantial component of total manufacturing sector. We find that in 2011-12, the share of top three states namely, Maharashtra, Gujarat and Tamil Nadu together accounted for 47.5 per cent of GSDP of the major 14 states (Table 2). In between, the share of top three states had declined to 46.2 per cent in 1993-94 and then to 45 per cent in 2004-05.

What happens to the manufacturing distribution if we expand the set of states to include recently carved out states? It is perhaps important not to ignore other remaining states and examine data for more recent years. We do this in Table 3 by considering 21 states and present data on the distribution of Net State Domestic Product (NSDP) in 
manufacturing ${ }^{12}$. We find that top three states have a combined share of 44.5 percent in 2015 16, the latest year for which data for all the 21 states is available. The three states are Maharashtra, Gujarat and Tamil Nadu, the same three states that dominated in the year way back in 1993-94.

Table 2: Distribution of Manufacturing GSDP By State

\begin{tabular}{|c|c|c|c|c|}
\hline State & 1980-81 & 1993-94 & 2004-2005 & 2011-2012 \\
\hline Maharashtra & 24.1 & 22.9 & 20.9 & 21.5 \\
\hline Tamil Nadu & 11.6 & 12.1 & 10.6 & 11.6 \\
\hline Gujarat & 8.6 & 11.2 & 13.5 & 14.4 \\
\hline Uttar Pradesh & 8.2 & 9.5 & 9.4 & 9.7 \\
\hline West Bengal & 11.8 & 7.2 & 5.7 & 4.6 \\
\hline Andhra Pradesh & 5.3 & 6.7 & 6.7 & 7.8 \\
\hline Madhya Pradesh & 5.6 & 6.1 & 2.6 & 1.6 \\
\hline Karnataka & 4.9 & 5.9 & 7.5 & 6.6 \\
\hline Bihar & 5.9 & 4.1 & 6.0 & 3.3 \\
\hline Punjab & 3.1 & 3.7 & 3.6 & 4.0 \\
\hline Haryana & 2.6 & 3.3 & 5.0 & 4.9 \\
\hline Rajasthan & 2.9 & 3.3 & 3.9 & 5.3 \\
\hline Kerala & 3.3 & 2.5 & 2.5 & 2.1 \\
\hline Orissa & 2.2 & 1.6 & 2.3 & 2.6 \\
\hline Above-14 States & 100 & 100 & 100 & 100 \\
\hline
\end{tabular}

Note: Shares Are Calculated Using The Values At Current Prices. For The Years 2004-05 And 201112 The 2004-05 Series Has Been Used.

Source: Estimates Based On Time Series Available At: http://www.epwrfits.in/

The problem of subnational concentration of registered manufacturing deserves more attention for the obvious reason that registered sector accounts for relatively larger share of total manufacturing output. We have estimated the trends in $\mathrm{HH}$ index of spatial concentration. Our measure of regional inequality is the spatial Herfindahl-Hirschman index (HH index) of concentration defined as follows:

$$
\text { HH Index }=\Sigma\left(\mathrm{s}_{\mathrm{i}}-\mathrm{x}_{\mathrm{i}}\right)^{2}
$$

Where, $\mathrm{s}_{\mathrm{i}}$ is the output (GSDP) share of the $\mathrm{i}^{\text {th }}$ state in total manufacturing output and $\mathrm{x}_{\mathrm{i}}$ is the share of the $\mathrm{i}^{\text {th }}$ state in the aggregate State Domestic Product (SDP). The HH index is a relative index that measures the extent to which an individual sector (manufacturing in our case) is spatially concentrated within a country. It compares the manufacturing output share 
of state relative to its share in total economy output. The spatial $\mathrm{HH}$ index is estimated for the 14 major states of India for the period 1980-81 to 2013-14 and is shown in Figure 2. The estimates of $\mathrm{HH}$ index clearly show an upright $\mathrm{U}$ shape that supports the proposition that spatial concentration in manufacturing output has been rising in recent years.

It is evident that spatial concentration of manufacturing output was declining in the 1980s. The years after 1990 do not show the kind of steep falls except in the year 1994-95. Spatial concentration in Indian manufacturing clearly shows an increasing trend particularly after 1995-96. The HH index has peak value in the year 2005-06. In the years after 2010, concentration index shows some decline but it is above the levels of $\mathrm{HH}$-index observed in 1990s and in the first half of 2000s. On this basis we might argue that spatial concentration is increasing in the post reform years. The decline in the 1980s is an outcome of industrial decline of West Bengal in particular and stagnation of the eastern states of Bihar and Orissa. The rise in spatial concentration levels could be directly attributed to the continuing dominance of Maharashtra, Tamil Nadu and Gujarat as the top three states with substantial share of manufacturing output. Another related piece of evidence that is consistent with spatial concentration is that the cumulative share of Maharashtra, Gujarat and Tamil Nadu in manufactured exports of India is found to be more than 54 per cent over the period 2000-08 (Pradhan and Das, 2016). It is found to be above 51 per cent in 2014-15 (Ramaswamy, 2017). This is consistent with the fact reported by the Economic Survey 2017-18 that the share of these top three states in total export of goods and services from India is above 50 per cent in 2018-19 (GOI, 2018). 


\begin{tabular}{|c|c|c|c|c|}
\hline States & 2004-05 & 2009-10 & 2013-14 & $2015-16 * *$ \\
\hline Maharashtra & 19.9 & 21.6 & 23.4 & 19.1 \\
\hline Gujarat & 11.9 & 14.6 & 13.7 & 14.3 \\
\hline Tamil Nadu & 9.7 & 10.8 & 11.3 & 11.1 \\
\hline Uttar Pradesh & 8.1 & 7.6 & 7.0 & 6.3 \\
\hline Karnataka & 6.9 & 6.0 & 5.9 & 7.5 \\
\hline West Bengal & 5.2 & 4.4 & 4.3 & 4.5 \\
\hline Jharkhand & 5.2 & 2.2 & 2.1 & 1.7 \\
\hline Haryana & 4.8 & 4.3 & 4.4 & 4.4 \\
\hline Rajasthan & 3.8 & 4.3 & 5.5 & 3.3 \\
\hline Punjab & 3.6 & 4.4 & 4.4 & 2.5 \\
\hline Andhra Pradesh & 3.5 & 2.8 & 2.5 & 2.9 \\
\hline Madhya Pradesh & 2.9 & 3.5 & 2.8 & 2.5 \\
\hline Telangana & 2.6 & 2.9 & 2.6 & 3.7 \\
\hline Chhattisgarh & 2.4 & 1.7 & 1.0 & 2.2 \\
\hline Kerala & 2.4 & 2.0 & 2.1 & 2.7 \\
\hline Delhi & 1.9 & 1.5 & 1.5 & 1.2 \\
\hline Odisha & 1.9 & 1.0 & 0.7 & 2.6 \\
\hline Bihar & 1.0 & 1.0 & 0.9 & 1.4 \\
\hline Goa & 0.9 & 0.8 & 0.7 & 1.3 \\
\hline Uttarakhand & 0.7 & 1.7 & 2.4 & 3.5 \\
\hline Himachal Pradesh & 0.7 & 0.8 & 0.8 & 1.4 \\
\hline HH Index-Absolute & 898 & 1016 & 1073 & 914 \\
\hline Above 21 states & 100 & 100 & 100 & 100 \\
\hline
\end{tabular}


Figure 2: Index of Spatial Concentration in Registered Manufacturing Output in India: 1981-2014

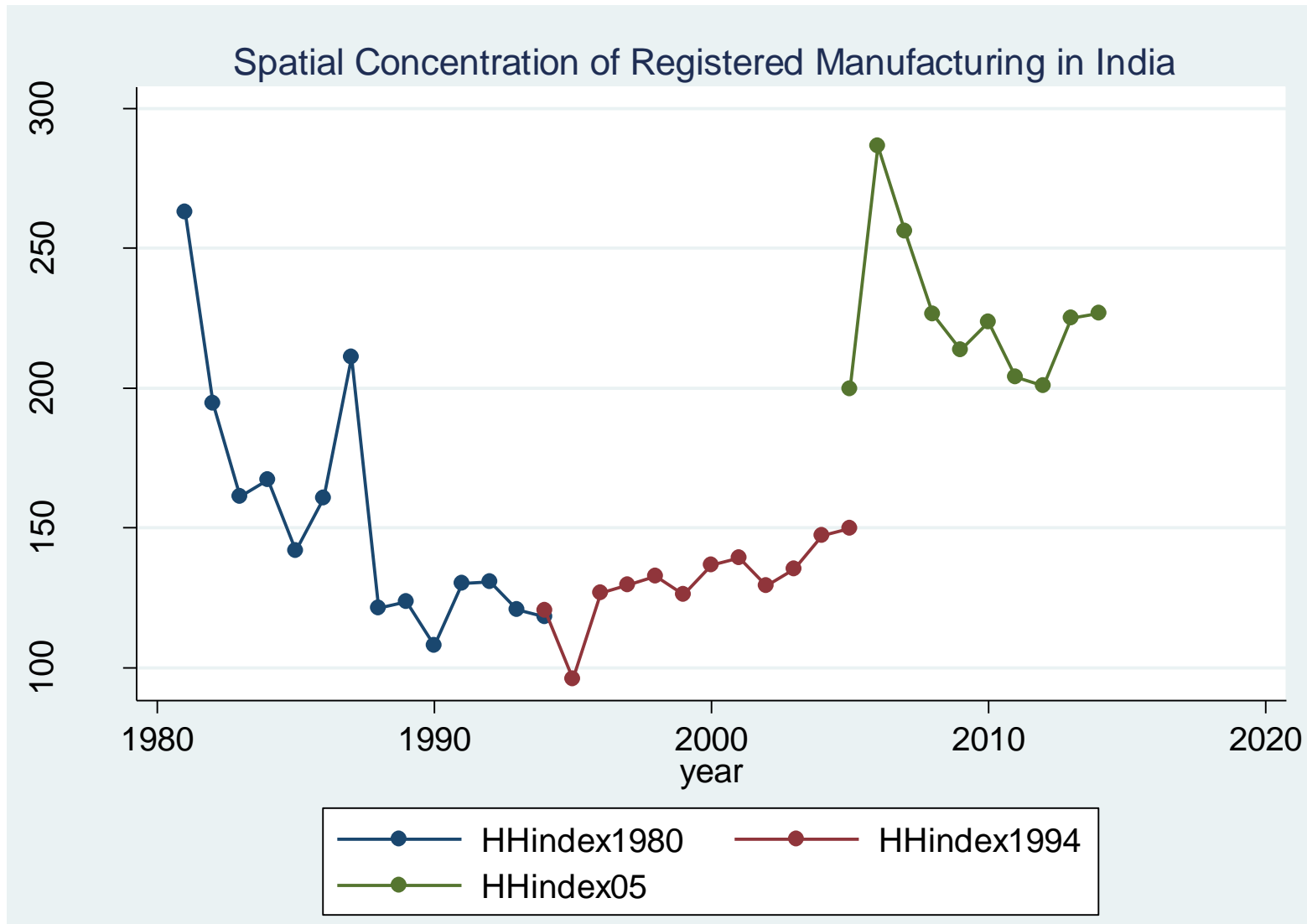

\subsection{Registered Manufacturing: Spatial Concentration of Factories}

What have been the changes in the distribution of factories and the entry of factories across states in recent years? Can we see the corresponding changes in the state-wise distribution of workers employed in registered manufacturing? These two are important and related questions in the context of our discussion. The growth of factories and the number of workers in registered manufacturing for the period 1994-95 to 2016-17 is presented in Table 4. The number of factories and workers have continuously risen beginning 2004-05 and their growth rate has substantially slowed down after 2011-12 ${ }^{13}$. We have examined changes in 
spatial concentration of factories and workers between 2004-05 and 2015-16 in twenty-one selected states of India.

Figure 3: Growth of Factories and Workers in Registered Manufacturing

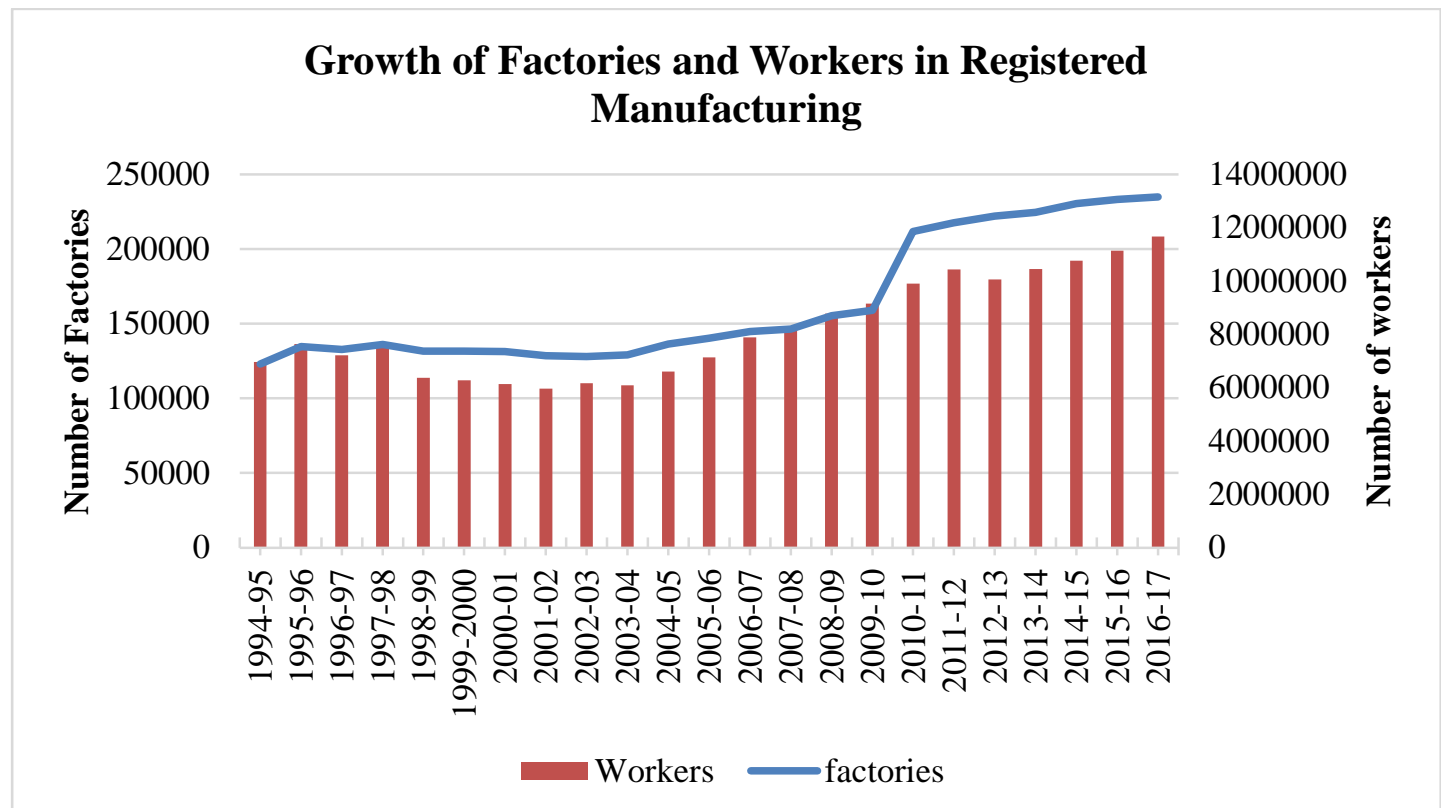

In order to capture the change in subnational concentration of factories and workers we have estimated the absolute version of $\mathrm{HH}$ index of concentration ${ }^{14}$. The absolute $\mathrm{HH}$ index is measured by the formula $\Sigma^{\mathrm{n}} \mathrm{S}_{\mathrm{i}}{ }^{2}$, where $\mathbf{n}$ is the total number of factories (workers) $\mathrm{S}_{\mathrm{i}}$ is the share of the $\mathrm{i}^{\text {th }}$ state in the total number of manufacturing factories (workers). If all the $\mathrm{n}$ states in India have the same size then the value of $\mathrm{HH}$ is equal to $1 / \mathrm{n}$. This is an absolute measure where the actual distribution is compared to the uniform distribution of the relevant variable under consideration like factories or workers in our case. The measured value of $\mathrm{HH}$ ranges between zero and 10,000 (maximum concentration) when the shares are expressed in percentages. A higher value of the $\mathrm{HH}$ index indicates greater spatial concentration of factories (workers). It gives greater weightage to larger states. It is one of the widely used measures of concentration along with 3-firm concentration ratio in the area of 
industrial economics. Our estimates of the $\mathrm{HH}$ index for the three selected years for the registered sector and the unorganized sector (more later) is presented in Table 4. They do not show any sign of decline in the subnational concentration of factories (workers) in registered manufacturing.

Table 4 : Spatial Concentration Indices for Indian Manufacturing

\begin{tabular}{lccc}
\hline & \multicolumn{3}{c}{ Registered Sector* } \\
\cline { 2 - 4 } & $2004-05$ & $2010-11$ & $2015-16$ \\
Factories & HH index & HH index & HH index \\
\cline { 2 - 4 } Workers & 914 & 957 & 916 \\
Net Value Added & 891 & 867 & 898 \\
& 975 & 1009 & 1092 \\
& Unregistered Sector** & \\
\cline { 2 - 4 } & $2005-06$ & $2010-11$ & $2015-16$ \\
Establishments & HH index & HH index & HH index \\
\cline { 2 - 4 } Workers & 871 & 837 & 826 \\
\hline \multicolumn{3}{c}{$*$ Author based on Annual Survey of Industries (ASI) of respective years } \\
\cline { 2 - 4 } & $* *$ Author based on NSSO enterprise surveys of respective years &
\end{tabular}

A closer look at the changes in the distribution of factories across factories and the entry of new factories (Net Entry) is possible and it is revealing (Table 5). The three top states (Tamil Nadu, Maharashtra and Andhra Pradesh) have a combined share of 42.2 percent, 44.3 percent and 42.7 percent in 2004-05, 2010-11 and 2015-16 respectively. The large improvement in the share of Andhra Pradesh has been due to increase in the number of factories in the state of Telangana. In terms of absolute number of net entry of factories Tamil Nadu topped the list with 21 percent (15795) of the total (73746) net entry of factories between 2005 and 2011. Andhra Pradesh contributed 14 per cent (10714) of total net entry followed by Maharashtra with 12 per cent (8980) and Gujarat with 10 per cent (7679) of net entry during the same period. Punjab is another significant state that has attracted 7 per cent (5195) followed by Uttar Pradesh (5\%), Karnataka (4\%), Rajasthan (3\%), Himachal Pradesh (2.1\%) and Uttarakhand (2.7\%). This pattern of net entry has enabled the top three states to maintain their top 3 positions in the year 2001-11. However a substantial slowdown in net 
entry has taken place in the period between 2011 and 2016 with the addition of only 21,272 factories against an addition of 73,746 factories in the earlier period. The two top losers were Maharashtra and Tamil Nadu which accounted for only 1.5 per cent and 2.3 per cent of the total net entry and their combined net entry was only 801 factories against 24,775 factories in the earlier period (2005-2011). Punjab is found to have negative net entry indicating that the total number of factories actually declined in the year 2016 relative to the year 2011. Of the 21 states only Haryana is found to have larger number of net entry of factories (the estimated number is 1986) during 2011-2016 compared to the earlier period. Two specific states needs to be mentioned namely, Himachal Pradesh and UttaraKhand, who have experienced significant decline in net entry in the second period. This outcome could be directly attributed to the withdrawal of tax incentives offered by the central government. We may recall that the excise tax incentives were withdrawn in 2010 and the corporate tax incentive had ended by 2012. Two states with relatively higher net entry were Karnataka (2251) and Andhra Pradesh (4928) that enabled them to maintain their overall share in the total number of factories in the year 2016. Taking the entire period together we find that more than 80 per cent of net entry has taken place in the states with above the Median number of factories consistent with the observed estimates of $\mathrm{HH}$ index of concentration in recent years ${ }^{15}$.

What has happened to the subnational distribution in terms of registered workers? Our estimates of state-wise distribution of workers and the net addition of workers by each state are shown in Table 6. The outcomes are similar with all the states having experienced significant slowdown in employment in the period between 2011 and 2016. However, the three top states Tamil Nadu, Maharashtra and Gujarat in 2015-16 contributed more than 46 percent of the total net addition 43 lakh workers over the entire period between 2005 and 2016. States that were successful in maintaining their employment shares have been Karnataka, Haryana, Uttar Pradesh and UttaraKhand. In short, disproportionate number 
factories and workers have gone to the initially industrialized states during the last decade.

The emergence of relatively new centres of manufacturing like Haryana, Karnataka, Andhra Pradesh including Telangana, Rajasthan and Uttarakhand has prevented further concentration of manufacturing activity.

Table 5: State-wise distribution of Factories and Net entry of Factories in Registered Manufacturing: 2005-2016

\begin{tabular}{|c|c|c|c|c|c|c|c|}
\hline & \multirow[b]{2}{*}{ States/UTs } & \multicolumn{3}{|c|}{$\begin{array}{c}\text { State-wise Distribution of } \\
\text { Factories }\end{array}$} & \multirow[t]{2}{*}{$\begin{array}{c}\text { Net } \\
\text { Entry of } \\
\text { factories: } \\
2010-11- \\
\text { over- } \\
\text { 2004-05 }\end{array}$} & \multirow[t]{2}{*}{$\begin{array}{c}\text { Net Entry } \\
\text { of } \\
\text { factories: } \\
2015-16 \\
\text { over-2010- } \\
11\end{array}$} & \multirow[t]{2}{*}{$\begin{array}{c}\text { Net } \\
\text { Entry of } \\
\text { factories: } \\
2015-16 \\
\text { over- } \\
\text { 2004-05 }\end{array}$} \\
\hline & & 2004-05 & 2010-11 & 2015-16 & & & \\
\hline 1 & Maharashtra & 14.4 & 13.6 & 12.4 & 8980 & 318 & 9298 \\
\hline 2 & Gujarat & 10.3 & 10.4 & 10.8 & 7679 & 3144 & 10823 \\
\hline 3 & Tamil Nadu & 16.0 & 17.9 & 16.5 & 15795 & 483 & 16278 \\
\hline 4 & Karnataka & 5.8 & 5.2 & 5.7 & 3126 & 2251 & 5377 \\
\hline 5 & Andhra Pradesh* & 11.8 & 12.8 & 13.8 & 10714 & 4928 & 15642 \\
\hline 6 & Uttar Pradesh & 7.3 & 6.7 & 6.7 & 4174 & 1535 & 5709 \\
\hline 7 & Haryana & 3.3 & 2.9 & 3.5 & 1628 & 1986 & 3614 \\
\hline 8 & Jharkhand & 1.2 & 1.2 & 1.2 & 897 & 327 & 1224 \\
\hline 9 & West Bengal & 4.6 & 4.0 & 4.1 & 2127 & 1068 & 3195 \\
\hline 10 & Rajasthan & 4.4 & 4.0 & 4.0 & 2432 & 877 & 3309 \\
\hline 11 & Madhya Pradesh & 2.3 & 2.0 & 2.0 & 1184 & 214 & 1398 \\
\hline 12 & Chhattisgarh & 1.0 & 1.1 & 1.3 & 1015 & 679 & 1694 \\
\hline 13 & Punjab & 5.7 & 6.2 & 5.5 & 5195 & -249 & 4946 \\
\hline 14 & Orissa & 1.3 & 1.2 & 1.3 & 787 & 412 & 1199 \\
\hline 15 & Himachal Pradesh & 0.5 & 1.1 & 1.2 & 1557 & 557 & 2114 \\
\hline 16 & Kerala & 4.2 & 3.4 & 3.3 & 1424 & 663 & 2087 \\
\hline 17 & Assam & 1.3 & 1.4 & 1.7 & 1085 & 1095 & 2180 \\
\hline 18 & Uttaranchal & 0.6 & 1.3 & 1.3 & 1987 & 239 & 2226 \\
\hline 19 & Goa & 0.4 & 0.3 & 0.3 & 65 & 71 & 136 \\
\hline 20 & Delhi & 2.4 & 1.9 & 1.7 & 764 & -144 & 620 \\
\hline \multirow[t]{2}{*}{21} & Bihar & 1.3 & 1.4 & 1.6 & 1131 & 818 & 1949 \\
\hline & Above 21 States & 100 & 100 & 100 & 73746 & 21272 & 95018 \\
\hline
\end{tabular}

Note: Share refers to the share of each state in the sum of 21 selected states. Source: Authors' based on ASI data of respective years 
Table 6: State-wise distribution of Number of Workers and Net addition of Workers in Registered Manufacturing: 2005-2016

State-wise Distribution of Workers

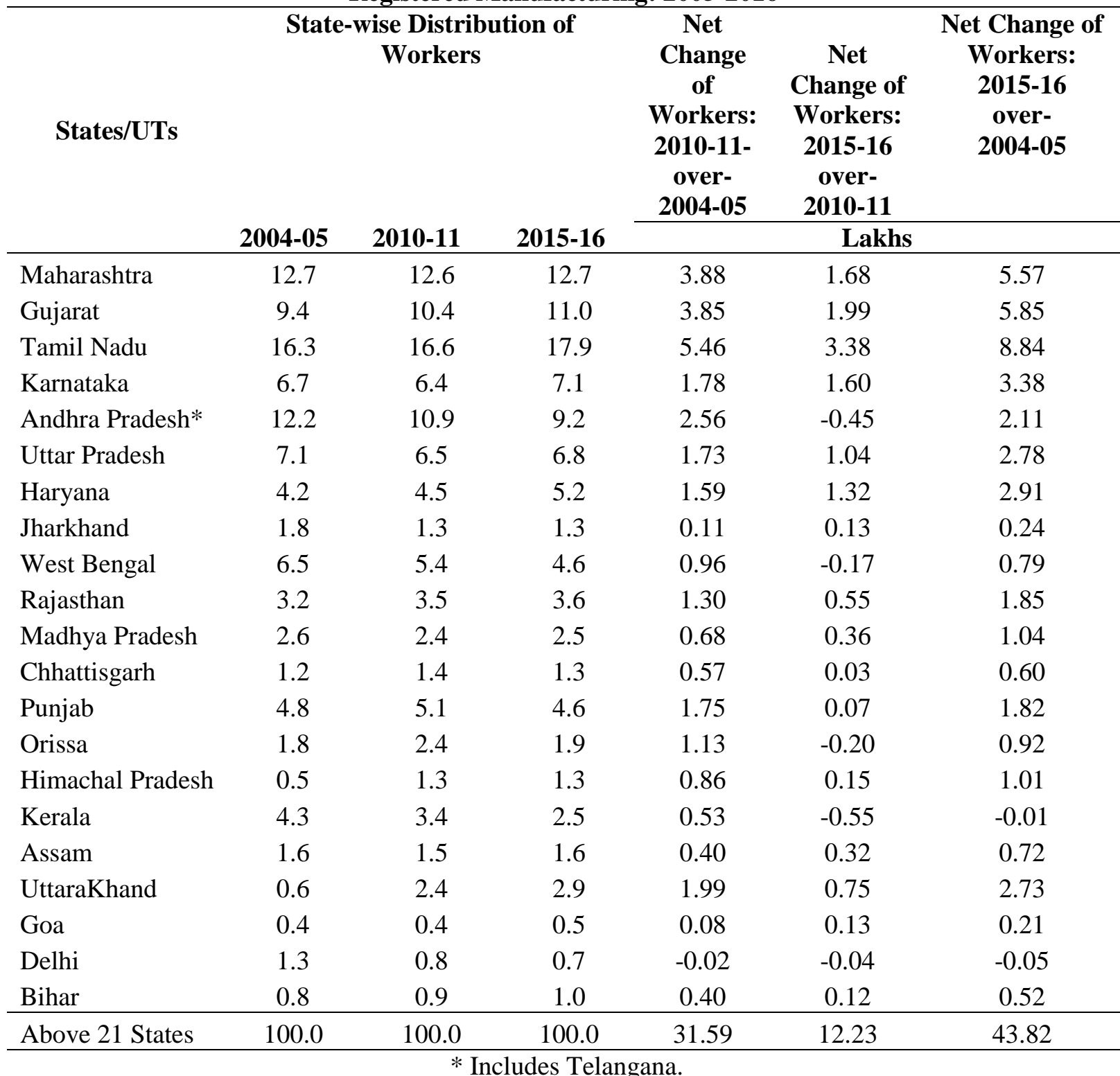

Note: Share refers to the share of each state in the sum of 21 selected states. Source: Authors' based on ASI data of respective years

\subsection{Unregistered Sector}

Does this pattern of outcome hold well in the case of unorganized or unregistered manufacturing sector? We have compared the distribution of establishments and net entry in three selected years 2005-06, 2010-11 and 2015-16, based on availability of NSSO surveys of unincorporated enterprises excluding construction. The estimated of distribution of 
establishments, and net entry in 21 states of India is presented in Table 7 and the corresponding information on the distribution of workers and net addition to workers in unorganized manufacturing in Table 8. The top three states are found to be Uttar Pradesh, West Bengal and Tamil Nadu with a combined share of 38.9 percent in 2005-06 and closely followed by Maharashtra in the fourth position. By 2015-16, the states of Uttar Pradesh and Maharashtra have lost shares but West Bengal and Tamil Nadu have maintained their shares because they experienced net entry of establishments over the ten year period. More significantly, Andhra Pradesh (78 thousand) and Gujarat (70 thousand) are found to have substantial net entry of establishments during the same period. Both have been observed to have positive net entry of factories in the registered sector (Table 5). In other words, the states of Gujarat and Andhra Pradesh have shown positive growth of factories and workers in both unregistered and registered sectors, a case of complementarity between formal and informal segments of manufacturing ${ }^{16}$. Similarly in Tamil Nadu registered and unregistered segments appear to complement each other by attracting the entry of both registered factories and unorganized establishments during the period 2005-2016. The differential performance of Tamil Nadu gets further support in the case of five individual industry groups in the registered sector. The state of West Bengal is found to be the top ranking state in unorganized manufacturing with the highest share of both establishments and workers. This finding is in sharp contrast to its dismal performance in the registered sector in terms of share of factories as well as workers. This contrasting pattern in the two segments of manufacturing sector in West Bengal clearly suggests the relatively large buildup of low productivity establishments and activities. In short, the case of West Bengal appears to be a good example of informalization even though the reasons are not immediately clear. It could reflect the prevalence of greater regulatory burden disincentivizing formal manufacturing growth. 
Table 7: State-wise Distribution of Establishments in Unorganized Manufacturing

\begin{tabular}{|c|c|c|c|c|c|c|}
\hline States & 2005-06 & 2010-11 & 2015-16 & $\begin{array}{l}\text { Net- } \\
\text { Entry- } \\
\text { 2011- } \\
\text { over } 2006\end{array}$ & $\begin{array}{l}\text { Net } \\
\text { Entry- } \\
\text { 2016- } \\
\text { over } \\
2011 \\
\end{array}$ & $\begin{array}{l}\text { Net- } \\
\text { Entry- } \\
\text { 2016- } \\
\text { over } 2006\end{array}$ \\
\hline & $\begin{array}{l}\text { Share } \\
(\%)\end{array}$ & $\begin{array}{l}\text { Share } \\
(\%)\end{array}$ & $\begin{array}{l}\text { Share } \\
(\%)\end{array}$ & \multicolumn{3}{|c|}{ Thousands } \\
\hline Uttar Pradesh & 13.5 & 11.0 & 11.8 & -26.7 & 26.0 & -0.7 \\
\hline West Bengal & 13.2 & 12.2 & 13.4 & 13.3 & 40.5 & 53.8 \\
\hline Tamil Nadu & 12.2 & 12.9 & 12.3 & 57.8 & -12.0 & 45.8 \\
\hline Maharashtra & 11.8 & 11.1 & 8.8 & 17.9 & -60.5 & -42.6 \\
\hline Andhra Pradesh & 7.1 & 9.2 & 9.0 & 79.7 & -1.6 & 78.1 \\
\hline Kerala & 6.8 & 4.6 & 4.6 & -39.6 & 2.2 & -37.4 \\
\hline Karnataka & 6.4 & 4.4 & 6.8 & -33.5 & 67.7 & 34.2 \\
\hline Gujarat & 5.5 & 8.8 & 7.6 & 108.2 & -28.6 & 79.6 \\
\hline Rajasthan & 3.5 & 3.5 & 4.1 & 11.3 & 19.1 & 30.3 \\
\hline Delhi & 3.3 & 5.0 & 4.2 & 56.6 & -19.6 & 37.0 \\
\hline Punjab & 2.9 & 3.9 & 3.3 & 35.3 & -13.0 & 22.3 \\
\hline Haryana & 2.8 & 1.7 & 1.9 & -20.7 & 4.5 & -16.2 \\
\hline Madhya Pradesh & 2.5 & 2.5 & 2.9 & 7.4 & 12.9 & 20.3 \\
\hline Bihar & 1.9 & 1.7 & 3.0 & -0.5 & 37.2 & 36.8 \\
\hline Odisha & 1.8 & 2.1 & 1.4 & 13.3 & -18.0 & -4.8 \\
\hline Assam & 1.8 & 2.2 & 1.8 & 18.2 & -10.6 & 7.6 \\
\hline Jharkhand & 1.2 & 1.0 & 1.0 & -1.9 & 0.6 & -1.3 \\
\hline UttaraKhand & 0.7 & 1.0 & 0.6 & 11.5 & -13.0 & -1.4 \\
\hline Chhattisgarh & 0.6 & 0.7 & 0.8 & 4.5 & 5.2 & 9.6 \\
\hline Himachal Pradesh & 0.4 & 0.5 & 0.6 & 2.2 & 3.7 & 5.9 \\
\hline \multirow[t]{2}{*}{ Goa } & 0.2 & 0.1 & 0.2 & -0.1 & 0.8 & 0.7 \\
\hline & 100 & 100 & 100 & 314.303 & 43.298 & 357.601 \\
\hline
\end{tabular}

Source: Authors' Estimates based on NSSO reports of respective years 
Table 8: State-wise Distribution of Workers in Unorganized Manufacturing

\begin{tabular}{|c|c|c|c|c|c|c|}
\hline \multirow[t]{2}{*}{ States } & $\begin{array}{l}\text { 2005- } \\
06 \\
\%\end{array}$ & $\begin{array}{l}2010- \\
11 \\
\%\end{array}$ & $\begin{array}{l}2015- \\
16 \\
\%\end{array}$ & $\begin{array}{l}\text { Net Addition } \\
\text { of } \\
\text { Workers:2011 } \\
\text {-over } 2006\end{array}$ & $\begin{array}{l}\text { Net Addition } \\
\text { of } \\
\text { Workers:2016 } \\
\text {-over 2011 }\end{array}$ & $\begin{array}{l}\text { Net Addition } \\
\text { of } \\
\text { Workers:2016 } \\
\text {-over } 2006\end{array}$ \\
\hline & & & & \multicolumn{3}{|c|}{ Lakhs } \\
\hline Maharashtra & 13.3 & 12.2 & 9.3 & 0.2 & -4.8 & -4.5 \\
\hline Tamil Nadu & 12.9 & 13.4 & 12.5 & 2.4 & -2.1 & 0.3 \\
\hline Uttar Pradesh & 12.3 & 12.2 & 12.5 & 1.5 & -0.6 & 0.9 \\
\hline West Bengal & 12.1 & 12.2 & 13.9 & 1.8 & 1.4 & 3.1 \\
\hline Gujarat & 8.1 & 11.7 & 10.5 & 6.1 & -2.4 & 3.8 \\
\hline Andhra Pradesh & 7.5 & 8.9 & 8.3 & 3.0 & -1.4 & 1.6 \\
\hline Karnataka & 6.9 & 4.0 & 6.3 & -3.1 & 2.6 & -0.5 \\
\hline Kerala & 5.7 & 3.7 & 3.8 & -2.0 & -0.2 & -2.2 \\
\hline Rajasthan & 4.0 & 3.1 & 3.7 & -0.7 & 0.7 & -0.1 \\
\hline Delhi & 3.4 & 4.6 & 4.7 & 2.1 & -0.3 & 1.8 \\
\hline Haryana & 2.5 & 2.0 & 2.0 & -0.4 & -0.1 & -0.5 \\
\hline Madhya Pradesh & 2.4 & 2.2 & 2.5 & 0.0 & 0.3 & 0.3 \\
\hline Punjab & 2.3 & 3.1 & 2.6 & 1.4 & -0.9 & 0.5 \\
\hline Odisha & 1.5 & 1.5 & 1.1 & 0.3 & -0.7 & -0.5 \\
\hline Assam & 1.3 & 1.5 & 1.5 & 0.5 & -0.2 & 0.3 \\
\hline Bihar & 1.1 & 1.1 & 2.0 & 0.1 & 1.1 & 1.2 \\
\hline Jharkhand & 0.9 & 0.9 & 1.0 & 0.1 & 0.1 & 0.2 \\
\hline Chhattisgarh & 0.7 & 0.7 & 1.0 & 0.1 & 0.3 & 0.4 \\
\hline UttaraKhand & 0.5 & 0.6 & 0.4 & 0.2 & -0.3 & -0.1 \\
\hline Himachal Pradesh & 0.3 & 0.4 & 0.4 & 0.1 & 0.0 & 0.1 \\
\hline Goa & 0.2 & 0.1 & 0.2 & -0.1 & 0.1 & 0.0 \\
\hline & 100.0 & 100.0 & 100.0 & 13.6 & -7.3 & 6.3 \\
\hline
\end{tabular}

Source: Authors' Estimates based on NSSO reports of respective years

\subsection{Industry Groups in Registered Manufacturing}

Our estimates of the distribution of registered factories and the changes in the relative contribution to net entry in two periods for the 5 selected two-digit industry groups is presented in Table A9 to Table A13 (see Appendix Tables below). The key points that emerged may be summarized as follows. In the Wearing Apparel (Garments) industry the state of Tamil Nadu dominated the scene with nearly 70 per cent share of the net entry of factories during 2005-2011 (35\% in 2016-11). Tamil Nadu also dominated the Motor Vehicles \& Parts industry with 37 per cent share of the net entry of factories during 2005-11 (23\% in 2011-16). It did not lag behind other leading states in Chemical \& Pharmacy 
industry by capturing 16 per cent of the net entry during 2011-16. Gujarat has persisted with its dominance of Chemical \& Pharmacy industry with 20 per cent share of Chemical \& Pharmacy and 16 per cent share in Rubber \& Plastics industry. Andhra Pradesh and Telangana have done well in Non-Metallic Mineral Products group (30\% share), Rubber\& Plastics (24\% share), and in Chemical \& Pharmacy (16\%) during the period 2011-2016.

\section{Concluding Remarks}

Our analysis of recent changes in the interstate distribution of factories and workers in the manufacturing has revealed that the spatial concentration of manufacturing activity has increased since 2004-05. Relatively more industrialized states have continued their dominance in terms of their share of factories and employment because of their greater share of incremental growth of factories and workers. In simple words, their comparative advantages as industrial location centres have not diminished over time. However, two states, namely, Telangana and Andhra Pradesh have performed well in terms of attracting factories and workers. The continuing dominance of Maharashtra, Gujarat and Tamil Nadu may be directly attributed their comparative advantages due to agglomeration economies. It suggests that in these states agglomeration benefits perhaps have continued to outweigh costs associated with agglomeration. States with initially well-developed industrial structure and

production experience have continued to enjoy their comparative advantage (History matters!). The post-reform period has also witnessed the substantial flow of foreign direct investment (FDI) into the states of Maharashtra, Gujarat, Tamilnadu and Karnataka. Available data on the number of investment proposals and the amount of FDI approved clearly indicates the concentration of FDI inflows in a few states. This confirms the strengthening of unequal tendencies in the distribution of domestic and foreign investment in the post-reform period. This finding should not be construed as arguments against agglomeration benefits. On the contrary, the deeper policy question yet to be answered is how 
do we go about creating and strengthening agglomeration forces in states other than the incumbent industrially advanced states? How to design industrial policies that foster the spatial spread of manufacturing? We must remember that spatial concentration driven by agglomeration by itself is not an undesirable feature as it contributes to productivity growth. The challenge is one of changing the expectations that drives disproportionate investment into the core areas and constraints the spread of manufacturing activity. Fiscal incentives have been the familiar instruments but we have sufficient evidence that they have largely failed in sustaining investment into backward states. Greater investment in infrastructure and education in the lagging regions of India is absolutely essential to encourage more spatial dispersion of industrial production without sacrificing efficiency. Interventionist policies could do well by focusing on factors that channel private investment into lagging states and regions. 
Appendix Tables

Table A9 : Wearing Apparel Industry: Distribution of Registered Factories and Net Entry

\begin{tabular}{|c|c|c|c|c|c|}
\hline State & $\begin{array}{l}\text { Share in } \\
\text { Total } \\
\text { factories- } \\
\mathbf{2 0 0 4 - 0 5} \\
(\%)\end{array}$ & $\begin{array}{l}\text { Share in } \\
\text { Total } \\
\text { factories- } \\
\mathbf{2 0 1 0 - 1 1} \\
(\%)\end{array}$ & $\begin{array}{l}\text { Share in } \\
\text { Total } \\
\text { factories- } \\
\mathbf{2 0 1 5 - 1 6} \\
(\%)\end{array}$ & $\begin{array}{l}\text { Relative } \\
\text { share in } \\
\text { Net Entry: } \\
\text { 2011-over } \\
2005(\%)\end{array}$ & $\begin{array}{l}\text { Relative } \\
\text { share in } \\
\text { Net Entry: } \\
\text { 2016-over } \\
2011(\%)\end{array}$ \\
\hline Tamil Nadu & 24.6 & 44.9 & 41.2 & 69.6 & 35.6 \\
\hline Karnataka & 18.4 & 7.8 & 9.3 & -5.2 & 11.6 \\
\hline Maharashtra & 16.9 & 9.1 & 10.4 & -0.4 & 12.3 \\
\hline Delhi & 15.2 & 6.9 & 5.5 & -3.0 & 3.2 \\
\hline Uttar Pradesh & 8.0 & 6.8 & 9.8 & 5.3 & 14.4 \\
\hline Haryana & 6.7 & 5.8 & 5.0 & 4.7 & 3.8 \\
\hline Rajasthan & 3.1 & 2.4 & 2.0 & 1.6 & 1.3 \\
\hline Gujarat & 3.1 & 3.0 & 3.5 & 3.0 & 4.1 \\
\hline Andhra Pradesh & 1.0 & 1.0 & 1.2 & 1.0 & 1.5 \\
\hline West Bengal & 1.0 & 1.6 & 2.5 & 2.4 & 3.7 \\
\hline Kerala & 0.9 & 0.4 & 0.3 & -0.3 & 0.3 \\
\hline Madhya Pradesh & 0.3 & 0.2 & 0.4 & 0.1 & 0.6 \\
\hline Punjab & 0.3 & 9.6 & 8.6 & 20.8 & 7.1 \\
\hline Himachal Pradesh & 0.2 & 0.0 & 0.1 & -0.1 & 0.2 \\
\hline Uttarakhand & 0.1 & 0.2 & 0.1 & 0.3 & -0.1 \\
\hline Orissa & 0.1 & 0.0 & 0.0 & -0.1 & 0.1 \\
\hline Assam & 0.0 & 0.1 & 0.0 & 0.1 & 0.0 \\
\hline Bihar & 0.0 & 0.0 & 0.0 & 0.0 & 0.1 \\
\hline Chhattisgarh & 0.0 & 0.0 & 0.1 & 0.0 & 0.2 \\
\hline Goa & 0.0 & 0.0 & 0.0 & 0.0 & 0.1 \\
\hline Jharkhand & 0.0 & 0.1 & 0.0 & 0.2 & -0.1 \\
\hline \multirow[t]{2}{*}{ Puducherry } & 0.0 & 0.1 & 0.0 & 0.1 & 0.0 \\
\hline & 100 & 100 & 100 & 100 & 100 \\
\hline
\end{tabular}

Source: Estimates Based On ASI data available at: http://www.epwrfits.in/ 
Table A10 : Chemical including Pharmacy: Distribution of Registered Factories and Net Entry

\begin{tabular}{lccccc}
\hline \multicolumn{1}{c}{ State } & $\begin{array}{l}\text { Share in } \\
\text { Total } \\
\text { factories- } \\
\text { 2004-05 }\end{array}$ & $\begin{array}{l}\text { Share in } \\
\text { Total } \\
\text { factories- } \\
\mathbf{2 0 1 0 - 1 1}\end{array}$ & $\begin{array}{l}\text { Share in } \\
\text { Total } \\
\text { factories- } \\
\mathbf{2 0 1 5 - 1 6}\end{array}$ & $\begin{array}{l}\text { Relative share } \\
\text { in Net Entry: } \\
\text { 2011-over } \\
\mathbf{2 0 0 5}\end{array}$ & $\begin{array}{l}\text { Relative share } \\
\text { in Net Entry: } \\
\text { 2016-over } \\
\mathbf{2 0 1 1}\end{array}$ \\
\hline Maharashtra & 19.8 & 16.0 & 16.4 & -21.7 & 17.3 \\
Tamil Nadu & 18.3 & 17.4 & 17.2 & 9.0 & 16.6 \\
Gujarat & 18.2 & 17.9 & 18.8 & 15.1 & 20.7 \\
Andhra Pradesh & 8.3 & 8.1 & 10.8 & 5.8 & 16.9 \\
Uttar Pradesh & 6.8 & 6.5 & 5.5 & 3.3 & 3.3 \\
Karnataka & 4.3 & 5.1 & 4.8 & 13.7 & 4.2 \\
West Bengal & 3.7 & 3.0 & 2.9 & -3.9 & 2.6 \\
Rajasthan & 3.2 & 3.1 & 2.5 & 2.2 & 1.2 \\
Madhya Pradesh & 2.8 & 3.1 & 2.6 & 6.9 & 1.5 \\
Haryana & 2.2 & 2.3 & 2.1 & 3.0 & 1.8 \\
Kerala & 2.2 & 2.2 & 1.9 & 2.5 & 1.2 \\
Punjab & 2.0 & 2.0 & 1.5 & 1.6 & 0.4 \\
Delhi & 1.3 & 0.8 & 0.7 & -4.5 & 0.5 \\
Puducherry & 1.2 & 1.1 & 0.9 & 0.3 & 0.6 \\
Goa & 1.0 & 0.9 & 0.6 & -0.3 & 0.1 \\
Himachal Pradesh & 1.0 & 3.4 & 4.2 & 27.5 & 5.9 \\
Orissa & 0.9 & 0.8 & 0.6 & -0.8 & 0.2 \\
Jharkhand & 0.7 & 1.0 & 0.6 & 4.2 & -0.3 \\
Uttarakhand & 0.7 & 3.7 & 3.5 & 33.9 & 3.2 \\
Assam & 0.6 & 0.6 & 0.8 & -0.2 & 1.2 \\
Chhattisgarh & 0.5 & 0.7 & 0.7 & 2.7 & 0.5 \\
Bihar & 0.5 & 0.4 & 0.5 & -0.4 & 0.6 \\
\hline & 100.0 & 100.0 & 100.0 & 100.0 & \\
\hline
\end{tabular}

Source: Estimates based On ASI data available at: http://www.epwrfits.in/ 
Table A11 : Rubber\& Plastic industry: Distribution of Registered Factories and Net Entry

\begin{tabular}{lccccc}
\hline \multicolumn{1}{c}{ State } & $\begin{array}{l}\text { Share in } \\
\text { Total } \\
\text { factories- } \\
\text { 2004-05 }\end{array}$ & $\begin{array}{l}\text { Share in } \\
\text { Total } \\
\text { factories- } \\
\mathbf{2 0 1 0 - 1 1}\end{array}$ & $\begin{array}{l}\text { Share in } \\
\text { Total } \\
\text { factories- } \\
\mathbf{2 0 1 5 - 1 6}\end{array}$ & $\begin{array}{l}\text { Relative share } \\
\text { in Net Entry: } \\
\text { 2011-over 2005 }\end{array}$ & $\begin{array}{l}\text { Relative share } \\
\text { in Net Entry: } \\
\text { 2016-over 2011 }\end{array}$ \\
\hline Maharashtra & 18.8 & 15.5 & 15.0 & -3.0 & 14.3 \\
Tamil Nadu & 12.4 & 13.9 & 11.4 & 22.3 & 7.6 \\
Gujarat & 11.8 & 11.4 & 13.4 & 9.3 & 16.4 \\
Andhra Pradesh & 10.7 & 9.9 & 15.5 & 5.9 & 23.9 \\
Uttar Pradesh & 7.7 & 8.1 & 7.5 & 10.5 & 6.6 \\
Kerala & 6.7 & 6.6 & 4.9 & 6.1 & 2.3 \\
Karnataka & 6.4 & 5.6 & 5.2 & 1.0 & 4.7 \\
West Bengal & 4.6 & 4.0 & 4.4 & 0.6 & 5.0 \\
Punjab & 3.4 & 3.3 & 2.4 & 2.6 & 1.0 \\
Rajasthan & 3.4 & 4.1 & 3.8 & 8.2 & 3.4 \\
Delhi & 2.8 & 2.5 & 2.0 & 0.6 & 1.2 \\
Madhya Pradesh & 2.4 & 2.3 & 2.1 & 1.5 & 1.9 \\
Haryana & 2.4 & 2.3 & 2.3 & 2.0 & 2.4 \\
Puducherry & 1.6 & 1.6 & 1.1 & 1.5 & 0.5 \\
Orissa & 0.8 & 0.8 & 0.6 & 0.3 & 0.3 \\
Himachal Pradesh & 0.8 & 1.9 & 1.8 & 7.8 & 1.8 \\
Jharkhand & 0.7 & 0.6 & 0.4 & 0.0 & 0.1 \\
Assam & 0.7 & 0.8 & 1.5 & 1.7 & 2.5 \\
Goa & 0.7 & 0.6 & 0.5 & -0.2 & 0.4 \\
Uttarakhand & 0.5 & 3.4 & 2.8 & 19.5 & 1.8 \\
Chhattisgarh & 0.4 & 0.6 & 0.8 & 1.4 & 0.9 \\
Bihar & 0.3 & 0.3 & 0.6 & 0.4 & \\
\hline & 100.0 & 100.0 & 100.0 & 100.0 & \\
\hline
\end{tabular}

Source: Estimates based on data available at: http://www.epwrfits.in/ 
Table A12 : Non-Metallic Mineral Products: Distribution of Factories and Net Entry

\begin{tabular}{lccccc}
\hline \multicolumn{1}{c}{ State } & $\begin{array}{l}\text { Share in } \\
\text { Total } \\
\text { factories- } \\
\mathbf{2 0 0 4 - 0 5}\end{array}$ & $\begin{array}{l}\text { Share in } \\
\text { Total } \\
\text { factories- } \\
\mathbf{2 0 1 0 - 1 1}\end{array}$ & $\begin{array}{l}\text { Share in Total } \\
\text { factories-2015- } \\
\mathbf{1 6}\end{array}$ & $\begin{array}{l}\text { Relative share in } \\
\text { Net Entry: 2011- } \\
\text { over 2005 }\end{array}$ & $\begin{array}{l}\text { Relative } \\
\text { share in Net } \\
\text { Entry: 2016- } \\
\text { over 2011 }\end{array}$ \\
\hline Andhra Pradesh & 19.5 & 20.0 & 23.9 & 21.8 & 30.5 \\
Rajasthan & 12.7 & 11.4 & 9.5 & 7.2 & 6.3 \\
Gujarat & 11.0 & 9.7 & 9.8 & 5.6 & 10.1 \\
Tamil Nadu & 7.4 & 7.9 & 7.2 & 9.4 & 6.1 \\
Kerala & 6.9 & 5.1 & 3.9 & -0.5 & 2.0 \\
Bihar & 6.0 & 5.8 & 6.0 & 5.1 & 6.4 \\
Maharashtra & 5.8 & 4.0 & 3.6 & -1.4 & 2.9 \\
Punjab & 5.3 & 10.0 & 8.1 & 24.8 & 4.9 \\
Uttar Pradesh & 4.3 & 6.1 & 4.7 & 11.7 & 2.2 \\
Jharkhand & 3.9 & 4.1 & 3.9 & 4.7 & 3.7 \\
Karnataka & 3.6 & 3.2 & 2.9 & 2.0 & 2.2 \\
Haryana & 3.0 & 2.3 & 4.4 & 0.2 & 7.9 \\
Assam & 2.7 & 3.5 & 5.4 & 6.0 & 8.8 \\
Orissa & 2.6 & 2.1 & 2.2 & 0.5 & 2.4 \\
Madhya Pradesh & 2.0 & 1.6 & 1.3 & 0.4 & 0.7 \\
West Bengal & 1.6 & 1.4 & 1.2 & 0.8 & 0.8 \\
Chhattisgarh & 0.6 & 0.6 & 1.0 & 0.5 & 1.8 \\
Uttarakhand & 0.5 & 0.5 & 0.3 & 0.6 & 0.0 \\
Himachal Pradesh & 0.3 & 0.4 & 0.3 & 0.7 & 0.1 \\
Delhi & 0.2 & 0.1 & 0.1 & -0.2 & 0.1 \\
Puducherry & 0.2 & 0.1 & 0.1 & 0.0 & 0.1 \\
Goa & 0.1 & 0.1 & 0.1 & 100.0 & \\
\hline All & 100.0 & 100.0 & 100.0 & 0.1 & \\
\hline
\end{tabular}

Source: Estimates based on data available at: http://www.epwrfits.in/ 
Table A13 : Motor Vehicles-trailers: Distribution of Factories and Net Entry

\begin{tabular}{lccccc}
\hline \multicolumn{1}{c}{ State } & $\begin{array}{l}\text { Share in } \\
\text { Total } \\
\text { factories- } \\
\text { 2004-05 }\end{array}$ & $\begin{array}{l}\text { Share in } \\
\text { Total } \\
\text { factories- } \\
\mathbf{2 0 1 0 - 1 1}\end{array}$ & $\begin{array}{l}\text { Share in } \\
\text { Total } \\
\text { factories- } \\
\mathbf{2 0 1 5 - 1 6}\end{array}$ & $\begin{array}{l}\text { Relative share } \\
\text { in Net Entry: } \\
\text { 2011-over 2005 }\end{array}$ & $\begin{array}{l}\text { Relative share in } \\
\text { Net Entry: 2016- } \\
\text { over 2011 }\end{array}$ \\
\hline Maharashtra & 25.9 & 22.2 & 23.5 & 11.6 & 26.6 \\
Tamil Nadu & 19.3 & 24.0 & 23.7 & 37.2 & 23.1 \\
Haryana & 9.3 & 10.6 & 10.1 & 14.3 & 8.9 \\
Karnataka & 8.6 & 7.5 & 8.5 & 4.6 & 10.8 \\
Uttar Pradesh & 6.5 & 4.5 & 4.8 & -1.3 & 5.5 \\
Punjab & 5.8 & 5.6 & 4.1 & 4.9 & 0.4 \\
Delhi & 5.5 & 3.9 & 2.8 & -0.7 & 0.1 \\
Andhra Pradesh & 4.2 & 2.4 & 3.0 & -2.7 & 4.7 \\
Gujarat & 3.9 & 3.4 & 3.5 & 1.9 & 3.9 \\
Jharkhand & 3.4 & 3.5 & 2.6 & 3.7 & 0.5 \\
Madhya Pradesh & 2.4 & 2.5 & 2.7 & 2.7 & 3.3 \\
West Bengal & 1.7 & 1.0 & 1.0 & -0.9 & 0.9 \\
Rajasthan & 1.7 & 1.8 & 2.1 & 2.3 & 2.7 \\
Kerala & 0.5 & 0.6 & 0.1 & 1.2 & -1.2 \\
Himachal Pradesh & 0.4 & 0.9 & 1.4 & 2.3 & 2.8 \\
Goa & 0.4 & 0.3 & 0.2 & 0.1 & 0.1 \\
Orissa & 0.2 & 0.1 & 0.1 & -0.1 & 0.2 \\
Assam & 0.1 & 0.1 & 0.1 & 0.1 & 0.1 \\
Puducherry & 0.1 & 0.2 & 0.3 & 0.6 & 0.4 \\
Uttarakhand & 0.1 & 4.8 & 5.2 & 18.2 & 5.9 \\
Bihar & 0.0 & 0.0 & 0.0 & 0.0 & 0.0 \\
Chhattisgarh & 0.0 & 0.0 & 0.1 & 0.0 & \\
\hline All & 100.0 & 100.0 & 100.0 & 100.0 & \\
\hline
\end{tabular}

Source: Estimates based on data available at: http://www.epwrfits.in/ 


\begin{tabular}{rlc}
\hline 1 & Goa & 30.0 \\
2 & Gujarat & 27.3 \\
3 & Haryana & 21.4 \\
4 & Maharashtra & 20.6 \\
5 & Tamil Nadu & 19.8 \\
6 & Karnataka & 18.4 \\
7 & Bihar & 17.8 \\
8 & Punjab & 15.1 \\
9 & Madhya Pradesh & 14.3 \\
10 & Uttar Pradesh & 13.4 \\
11 & Rajasthan & 12.5 \\
12 & Andhra Pradesh & 12.2 \\
13 & Odisha & 12.1 \\
14 & Himachal Pradesh & 11.5 \\
15 & West Bengal & 11.1 \\
16 & Assam & 10.5 \\
17 & Kerala & 8.6 \\
18 & Delhi & 7.3 \\
\hline
\end{tabular}

Source: EPWRF data base available at: http://www.epwrfits.in/

Note: 2004-05 Series At Constant Prices

*Bihar Includes Jharkhand; MP Includes Chhattisgarh; UP Includes Uttarkhand; Andhra Pradhesh includes Telangana

\section{References:}

Ahluwalia, M. S. 2000. 'Economic Performance of States in Post Reform Era',

Economic and Political Weekly, Vol. 35, No. 19, pp 1638-48, May 2000

Chaurey, Ritam.2017. "Location-based tax incentives: Evidence from India." Journal of Public Economics, vol. 156, pp. 101-120.

Ghose, Ajit. 2016. India Employment Report, Institute for Human Development and Oxford University Press, Delhi, 2016. 
Government of India. 2018. Economic Survey 2017-18, Volume I, Ministry of Finance, New Delhi.

Kanbur, Ravi, Anthony J.Venables. 2005. Spatial Inequality and Development. Oxford New York: Oxford University Press

Krugman, Paul. 1991. "Increasing Returns and Economic Geography," Journal of Political Economy, 99 (3): 483-499.

Krugman, Paul. 1998. "The Role of Geography in Development", in B.Pleskovic and J.Stiglitz (Eds), Annual World bank Conference on Development Economics (ABCDE) 1998, Washington, D.C., The World Bank.

Lall, S. and S.Chakravorty 2005, 'Industrial Location and Spatial Inequality: Theory and Evidence from India', Review of Development Economics, 9 (1): 47-68

Lall, S. and S. Chakravorty 2007, Made in India: The Economic Geography and Political Economy of Industrialization, New Delhi: Oxford University Press

Lessmann, C. 2014, 'Spatial Inequality and Development-Is there an inverted-U Relationship?' Journal of Development Economics, No.106 (January): 35-51

Marathe, S. S. 1989. Regulation and Development: India's Policy Experience of Controls over Industry. SAGE Publications, New Delhi.

Mohan, R.1993, 'Industrial Location Policies and Their Implications for India', Paper.No.9, Studies in Industrial development, New Delhi: Ministry of Industry

Myrdal, G. 1957. "Economic Theory and Underdeveloped Regions", London

Nayyar, G.2008. 'Economic Growth and Regional Inequality in India', Economic and Political Weekly, 43(6):58-67 
National Sample Survey Organization (2007a): NSS 62nd Round (July 2005-June 2006); Report No. 524(62/2.2/1), Operational Characteristics of Unorganized Manufacturing Enterprises, Ministry of Statistics and Programme Implementation, Government of India

National Sample Survey Organization (2007b): NSS 62nd Round (July 2005-June 2006); Report No. 525(62/2.2/2), Unorganised Manufacturing Sector in India: Employment, Assets and Borrowings, Ministry of Statistics and Programme Implementation, Government of India

National Sample Survey Organization (2012): NSS 67th Round (July 2010 - June 2011); Report No.KI (67/2.34), Key Results of Survey on Unincorporated Non-agricultural Enterprises (Excluding Construction) in India, Ministry of Statistics and Programme Implementation, Government of India

National Sample Survey Organization (2013): NSS 67th Round (July 2010 - June 2011); Report No. 549(67/2.34/2), Economic Characteristics of Unincorporated Non-agricultural Enterprises (Excluding Construction) in India, Ministry of Statistics and Programme Implementation, Government of India

National Sample Survey Organization (2017): NSS 73 ${ }^{\text {rd }}$ Round (July 2015 - June 2016); Report No.KI (73/2.34), Key Indicators of Unincorporated Non-Agricultural Enterprises (Excluding Construction) in India; Ministry of Statistics and Programme Implementation, Government of India.

National Sample Survey Organization (2018): NSS 73rd Round (July 2015 - June 2016); Report No.581 (73/2.34/1), Operational Characteristics of Unincorporated Non-Agricultural Enterprises (Excluding Construction) in India; Ministry of Statistics and Programme Implementation, Government of India.

Pradhan, J and Keshab, Das, 2016, Manufacturing Exports from Indian States: Determinants and Policy Imperatives, Springer India 
Rodriguez-Pose A. 2012. 'Trade and Regional Inequality'. Economic Geography, 88(2): 109136

Ramaswamy, K.V. 2007. 'Regional Dimension of Growth and Employment', Economic and Political Weekly, 42(49):47-56

Ramaswamy, K.V.2011. 'Regional Disparities in Manufacturing Growth in India' In D.M.Nachane (Ed), India Development Report 2011, Oxford University Press, New Delhi

Ramaswamy, K.V. and Tushar Agrawal, 2012. 'Services-led Growth, Employment, and Skill and Job Quality: A study of Manufacturing and Service Sectors in Urban India', in S.Mahendra Dev (ed), India Development Report 2012-13, Oxford University Press, New Delhi

Ramaswamy, K.V. 2015. 'Introduction' in Labour, Employment and Economic Growth in India, edited by K.V.Ramaswamy, Cambridge University Press, New Delhi

Ramaswamy, K.V. (2017). “Growth, Structural Change and Spatial Inequality in India: Some Dimensions of Regional Disparity", Korea Institute of International Economics Policy (KIEP), 2016 KIEP Visiting Fellows Program, KIEP, 2017

Reserve Bank of India (2015), Handbook of Statistics on Indian Economy 2016-17, RBI, Mumbai.

Shruti J Pandey, S L Shetty.2014. "ASI Results for 2011-12: A More Positive View of the Industrial Scene", Economic \& Political Weekly, May 24, No. 21:89-93

Sekhar, A.U. 1983. 'Industrial Location Policy: The Indian Experience', World Bank Working Paper No.620, Washington DC: The World Bank, 
1 At 2011-12 prices

${ }^{2}$ We must note that the level of industrialization measured in terms of manufacturing sector's share in State Domestic Product has undergone changes in recent years. All the four new states, Jharkhand, Chhattisgarh, Uttarkhand and Telangana are found to have been more industrialized than their parent states, Bihar, Madhya Pradesh, Uttar Pradesh and Andhra Pradesh respectively in the year 2004-05 (See Table A14 in Appendix Tables). They are all relatively small states in terms of their share in population and national output. In short changes in sector shares due to subdivision of geographical boundaries is not be confused with structural transformation of subnational economies.

${ }^{3}$ It has been argued, based on the idea of cumulative causation that industrialization follows the principle of "virtuous cycle" and therefore new industrial firms tend to locate themselves in already developed regions or locations to take advantage of agglomeration economies. See Myrdal (1957) for the original concept. See Lall and Chakravorty (2005) and Chakravorty and Lall (2007) for a recent application of the argument in the context of industrialization in India.

${ }^{4}$ This section is substantially draws from Ramaswamy (2011) and Ramaswamy (2016).

${ }^{5}$ This section is based on Sekhar (1983) and Mohan (1993)

${ }^{6}$ See Sekhar (1983) for an early detailed discussion of these policies. Also see Marathe (1989)

7 This paragraph is based on Chaurey (2017) and the original notification is available at http//taxguru.in/excise-duty/notification-50-2003 central-excise-dated-10th-june2003.html, accessed on April 25, 2019.

${ }^{8}$ See Chaurey (2017).

${ }^{9}$ This section is based on Ramaswamy (2017)

${ }^{10}$ Estimated by Chakravorty and Lall (2007).

${ }^{11}$ We say probably because we have not estimated the index of spatial inequality for the 1970s. The estimates of HH index reported by Mohan (1993) are absolute HH indexes and are not comparable with ours.

${ }^{12}$ The data on NSDP with 2004-05 base is not available for many states for the year 2014-15.

${ }^{13}$ The sudden jump observed in the number of factories in the year 2010-11 is because of change in the method of recording codes for estimating the number of factories. See Shruthi and Shetty (2014). As we are concerned with the distribution of factories across space this should not affect our results.

${ }^{14}$ We have used the absolute version because the relative concentration measure is affected by extreme values of small sized sub-national units (states in India).

${ }^{15}$ The state of Haryana with 4339 factories is found to be the median state in 2004-05.

${ }^{16}$ We have not investigated the performance and the contribution of Telangana to this finding of good growth in both registered and unregistered sectors of manufacturing. 